\title{
Menggali Nilai Siri' Na Pacce Sebagai Tinjauan Sosiologis Pembentukan Perda Anti Korupsi
}

\author{
Fadillah Gerhana Ultsani ${ }^{1}$, Reza Aviva Prastika ${ }^{2}$, Herlin Herlin ${ }^{3}$, \\ Moch. Andry Wikra Wardana Mamonto ${ }^{4}$ \\ 1,2,3,4 Ilmu Hukum, Universitas Muslim Indonesia \\ Email Correspondensi: herlinbufri12@gmail.com \\ No. HP Correspondensi: +62 82347708111
}

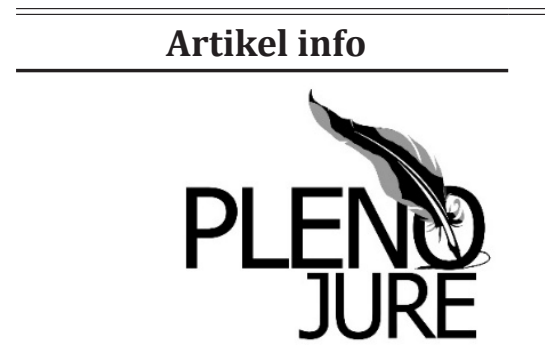

Jurnal Ilmu Hukum LL-DIKTI Wilayah IX Sulawesi

\footnotetext{
Artikel history:

$\begin{array}{lr}\text { Received : } & \text { 22 Juni, } 2019 \\ \text { Revised : } & 18 \text { Juli, } 2019\end{array}$

Accepted : 14 Agustus, 2019
}

\begin{abstract}
Abstrak Undang-Undang No. 31 Tahun 1999 mengatur tentang pemberantasan tindak pidana korupsi di Indonesia. Tetapi, keberadaan undang-undang tidak menjadi penghalang bagi seseorang melakukan praktik korupsi. Berdasarkan survei Internasional Transparency tahun 2017 indeks persepsi korupsi, Indonesia berada pada peringkat 96 pada skor 37 yang membuat Indonesia berada dalam kondisi darurat korupsi dan salah satu penyebab korupsi adalah budaya. Di Indonesia, khususnya Sulawesi Selatan terdapat budaya Siri' Na Pacce yang menjadi pandangan hidup dan bertingkah laku bagi masyarakat Bugis-Makassar. Penelitian ini dilakukan untuk mencari tahu apakah terdapat nilai anti korupsi pada budaya Siri' Na Pacce. Untuk menjawab rumusan masalah dalam penelitian ini, digunakan Penelitian normatif empiris. Dalam penelitian normatif empiris kita membutuhkan data sekunder dan data primer, yang dimana data sekunder yakni data yang diperoleh dari buku-buku sebagai data pelengkap sumber data primer, yang terdiri atas: Bahan hukum primer, bahan hukum sekunder, dan bahan hukum tersier, yang kedua adalah data primer, yang merupakan data yang diperoleh dari hasil penelitian lapangan melalui wawancara terkaitobjek penelitian. Berdasarkan hasil penelitian menunjukkan bahwa adanya korelasi antara nilai anti korupsi dalam nilai budaya Siri na Pacce namun kian menipis sehingga dengan penelitian ini nilai budaya Siri na Pacce yang ada di masyarakat Bugis-Makassar bisa ditumbuhkan dan diangkat menjadi norma berupa Peraturan Daerah Sulawesi Selatan.
\end{abstract}

Abstract. Act no. 31 of 1999 regulates about eradication of criminal act of corruption in Indonesia. But the existence of the act is no obstacle towards someone to commit corruption practicing. Following transparency international survey in 2017 about corruption perception index, Indonesia was getting the rank at 96 on the score of 37 that have been making Indonesia is in an emergency state of corruption and one of causes of corruption is culture. In Indonesia especially Sulawesi Selatan, There 
Keywords:

Budaya;

Siri' na Pacce;

Pembentukan Perda;

Anti Korupsi. has the famous culture named Siri'na pacce which is as view of life and behavior for Bugis-Makassar society. This research is conducted to find out whether there is an anti-corruption value in Siri'na pacce culture. To answer the problem formula in this research, normatif-empirical research is used. In the normative empirical research we need secondary and primary data, where the secondary data is the data obtained from the books as auxiliary data of primary source data, consisting of: primary legal material, secondarylegal material, and tertiaryingredient, the second primary data, which is data obtained by field research interviews related to object of research. Based on result of research, that reveals there's a correlation between the anti-corruption values in the cultural value of siri na pacce but is increasingly thinning so that through this research, the value of Siri na pacce culture in BugisMakassar can be grown and raised becomes regional regulation in South Sulawesi.

artikel dengan akses terbuka dibawah lisensi CC BY -4.0

\section{PENDAHULUAN}

Indonesia merupakan Negara dengan peringkat 96 (Sembilan puluh enam) Negara terkorup dengan skor 37 ( 0 sangat korup, 100 sangat bersih) berdasarkan hasil survei Transparency International yang dirilis pada tahun 2017 tentang Indeks Persepsi Korupsi. Di peringkat ini Indonesia sama dengan Brazil, Colombia, Panama, Peru, dan Zambia. Kemudian pada tahun 2018 dilakukan survei kembali oleh Transparency International, dan peringkat Indonesia dinyatakan naik yakni menjadi peringkat 89, akan tetapi masih dengan skor 38.

Berbagai upaya pemberantasan korupsi terus dilakukan dari setiap rezim pemerintahan termasuk di era reformasi. Pemberantasan korupsi merupakan salah satu tuntutan yang diminta oleh masyarakat. Adapun jawaban tuntutan reformasi yang berhubungan dengan pemberantasan korupsi yaitu dengan kebijakan pembentukan lembaga yang secara khusus untuk menangani kasus-kasus korupsi, lembaga ini dikenal dengan Komisi Pemberantasan Korupsi (KPK) yang keberadaannya diatur dalam UndangUndang Nomor 30 Tahun 2002, pembaharuan langkah pemberantasan korupsi dapat juga dilihat dengan adanya Undang-Undang Nomor 31 Tahun 1999 tentang Tindak Pidana Korupsi.

Namun nyatanya, kebijakan-kebijakan tersebut belum mampu menjadi penekan angka korupsi di Indonesia, sebagaimana data dirilis oleh Transparency International yang menunjukkan Indonesia masih berada dalam kondisi darurat korupsi. Indonesia yang masih berada pada kondisi darurat korupsi memberikan peringatan untuk terus mencari dan 
merumuskan strategi guna mencegah dan memberantas korupsi, dalam mencari rumusan strategi pencegahan dan pemberantasan korupsi terlebih dahulu mengetahui dan memahami faktor penyebab terjadinya korupsi.

Berdasarkan penelitian Knack, Lee, dan Azfar menyimpulkan bahwa budaya merupakan salah satu faktor korupsi, maka secara a contrario untuk melawan praktik korupsi juga dapat dilakukan dengan budaya ${ }^{1}$. Di Indonesia terdapat berbagai budaya, salah satunya yakni di Sulawesi Selatan yaitu budaya Siri' Na Pacce. ${ }^{2}$ Siri' Na Pacce sendiri merupakan sebuah nilai budaya yang dijadikan pedoman oleh masyarakat suku Bugis-Makassar dalam menjalani kehidupan sehari-hari. Rasa harga diri dan kehormatan sebagai esensi Siri' secara implementasi membawa serta pengertian malu, yakni suatu rasa yang timbul akibat adanya perkosaan terhadap harga diri dan kehormatan. ${ }^{3}$

Budaya Siri' Na Pacce lebih menuntut agar orang-orang menjalankan kewajibannya dengan sebaik-baiknya karena memiliki tanggung jawab sosial. Selain itu, dengan menjunjung tinggi harga diri dalam bekerja maka akan membuat individu lebih giat, amanah, serta mengaplikasikan nilainilai kejujuran. ${ }^{4}$

Apabila Siri' Na Pacce sebagai pandangan hidup tidak dimiliki oleh seseorang, akan dapat berakibat orang tersebut bertingkah laku seenaknya karena tidak memiliki unsur kepedulian sosial dan hanya mau menang sendiri ${ }^{5}$ ). Menggali nilai budaya untuk penyusunan kebijakan adalah jalan yang tepat, sebagaimana pandangan yang dikemukakan oleh Eugen Elrich bahwa "hukum yang baik adalah hukum yang hidup dalam masyarakat"

Dengan demikian, untuk mencegah praktik korupsi di Provinsi Sulawesi Selatan maka penting untuk dilakukan penggalian nilai-nilai budaya Siri' $\mathrm{Na}$ Pacce sebagai tinjauan sosiologis pembentukan Peraturan Daerah Anti Korupsi. Bagaimanakah nilai-nilai anti korupsi yang terkandung dalam nilai budaya Siri' Na Pacce masyarakat Bugis-Makassar?

\section{METODE}

Dilihat dari segi fokus kajiannya, penelitian hukum yang dilakukan oleh tim termasuk jenis penelitian normatif-empiris. Dimana penelitian hukum normatif adalah penelitian hukum yang dilakukan dengan memilih

${ }^{1}$ Swamy, Anand, Knack, Stephen, Lee, Young, \& Azfar, Omar. (2001). Gender and Corruption. Journal of Development Economics, 64(1), hlm. 25 - 55.

${ }^{2}$ Qamar, Nurul, Syarif, Muhammad, Busthami, Dachran S., Khalid, Hasbuddin, Rezah, Farah Syah, \& Muzakkir, Abd. Kahar. (2018). Menguak Nilai Kearifan Lokal Bugis Makassar: Perspektif Hukum dan Pemerintahan. Makassar: CV. Social Politic Genius (SIGn).

${ }^{3}$ Marzuki, M. Laica. (1995). Siri': Bagian Kesadaran Hukum Rakyat Bugis-Makassar. Ujung Pandang: Hasanuddin University Press, hlm. 4.

${ }^{4}$ Rusdi, Mughny Ilman Wali, \& Prasetyaningrum, Susanti. (2015). Nilai Budaya Siri' Na Pacce dan Perilaku Korupsi. Indigenous: Jurnal Ilmiah Psikologi, Universitas Muhammadiyah Surakarta, 13(2), hlm. $70-71$.

${ }^{5}$ Ibid., hlm. 70.

${ }^{6}$ Wahid, Muhammad Yunus. (2011). Prinsip dan Karakter Hukum Lingkungan. Ishlah: Jurnal Ilmiah Hukum, UMI Makassar, 13(2), hlm. 5 - 23. 
bahan pustaka atau data sekunder yang difokuskan pada salah satu macam jenis, meliputi: asas hukum, sistematika hukum, sinkronisasi vertikal dan horizontal, perbandingan hukum, dan sejarah hukum ${ }^{7}$. Sedangkan penelitian hukum empiris adalah penelitian yang utamanya meneliti data yang diperoleh langsung dari sumber ${ }^{8}$

Merujuk pada Sugeng Istanto sifat dari penelitian ini ialah bersifat Deskriptif-Eksploratoris, yaitu: 1) deskriptif: peneliti dalam menganalisis bertujuan untuk mengungkapkan kebenaran atau menggambarkan suatu kebenaran dalam keadaan seperti apa adanya. 2) eksploratoris: peneliti dalam menganalisis berkeinginan bertujuan mengungkapkan kebenaran dari suatu penelitian yang bertujuan menjajaki keberadaan suatu kebenaran?

Adapun pendekatan yang digunakan untukmenjawab rumusan masalah dalam penelitian hukum menggunakan beberapa pendekatan. Pendekatan (approach) merupakan salah satu cara untuk mendekati objek penelitian ${ }^{10}$. Pendekatan tersebut meliputi pendekatan perundang-undangan (statutory approach), pendekatan konseptual (conceptual approach), pendekatan sejarah (history approach).

Data yang dibutuhkan dalam penelitian hukum normatif-empiris adalah data sekunder dan data primer. Data sekunder adalah data yang diperoleh dari hasil penelaahan kepustakaan atau penelaahan terhadap berbagai literatur atau bahan pustaka yang berkaitan dengan korupsi dan nilai budaya Siri' Na Pacce. Sedangkan, data primer adalah data yang diperoleh dari narasumber berkompeten dengan teknik wawancara terbuka atau wawancara tanpa daftar pertanyaan, yaitu: (1) Aminuddin Salle adalah Ketua Asosiasi Pengajar Hukum Adat; (2) Serang Dakko adalah Ketua Sanggar Budaya Serang Dakko; dan (3) Abdi Mahesa adalah Budayawan Sulawesi Selatan ${ }^{11}$

Adapun data sekunder adalah data yang diperoleh dari buku-buku sebagai data pelengkap sumber data primer, terdiri dari: Bahan hukum primer yaitu bahan hukum yang bersifat otoritatif yang artinya mempunyai otoritas (mengikat). Bahan hukum sekunder yaitu bahan hukum yang memberikan penjelasan terhadap bahan hukum primer ${ }^{12}$

Penelitian hukum normatif-empiris dilaksanakan melalui 2 (dua) tahap, yaitu Pertama, tahap pelaksanaan. Pada tahap ini, peneliti melakukan penelitian berupa studi pustaka (dokumen) dan studi lapangan. Dalam studi pustaka dilakukan pemilahan dan pengumpulan data-data yang terkait dengan objek kajian yang diteliti. Hasil penelitian sementara data

${ }^{7}$ Muhammad, Abdulkadir. (2004). Hukum dan Penelitian Hukum. Bandung: PT. Citra Aditya Bakti, hlm. 52.

${ }^{8}$ Ibid., hlm. 40 - 54

${ }^{9}$ Istanto, F. Sugeng. (2007). Penelitian Hukum. Yogyakarta: CV. Ganda, hlm. 9.

${ }^{10}$ Syamsuddin, M. (2007). Operasionalisasi Penelitian Hukum. Jakarta: PT. Raja Grafindo Persada, hlm. 56.

${ }^{11}$ D., Mukti Fajar N., \& Achmad, Yulianto. (2015). Dualisme Penelitian Hukum: Normatif \& Empiris. Yogyakarta: Pustaka Pelajar, hlm. 156.

${ }^{12}$ Ibid. 
sekunder dikonsultasikan kepada pembimbing untuk memperoleh masukan. Kemudian dilanjutkan dengan studi lapangan yang erat kaitannya dengan permasalahan yang dibahas dengan cara wawancara narasumber yang berkompeten dalam penelitian ini. Hasil sementara pengolahan data primer ini dikonsultasikan dengan pembimbing untuk memperoleh masukan guna tersistematisasinya penyusunan laporan kemajuan penelitian ini.

Kedua, ialah tahap penyelesaian. Pada tahap ini dilakukan dengan membuat suatu laporan atas hasil penelitian. Laporan disusun dengan sistematis dan terstruktur sesuai pedoman penulisan yang dijadikan acuan. Kemudian laporan hasil penelitian ini dikonsultasikan dengan pembimbing dan dibuat laporan akhir. Dalam penelitian ini proses analisis data menggunakan metode kualitatif. Metode kualitatif ialah suatu tata cara penelitian yang menghasilkan data deskriptif-eksploratoris, yang mempelajari objek penelitian sebagai sesuatu yang utuh sehingga dapat mengungkapkan serta memahami kebenaran atas objek tersebut ${ }^{13}$

\section{HASIL DAN PEMBAHASAN}

Salah satu yang diatur dalam Undang-Undang Dasar Negara Republik Indonesia Tahun 1945 (UUD NRI 1945) sebagai dasar hukum tertinggi di Indonesia, adalah otonomi daerah pada Pasal 18.

Otonomi daerah yang artinya 'autos' yang berarti sendiri dan 'nomos' berarti aturan. Maka dapat diartikan sebagai pengaturan sendiri atau mengatur sendiri. Adapun dalam Undang-Undang 23 Tahun 2014 tentang Pemerintahan Daerah, yaitu otonomi daerah hak, wewenang, dan kewajiban daerah otonom untuk mengatur dan mengurus sendiri urusan pemerintahan dan kepentingan masyarakat setempat. Salah satu hal bentuk pemberian otonomi daerah yaitu kewenangan untuk membentuk peraturan daerah.

Dalam Undang-Undang Nomor 12 Tahun 2011 bahwa setiap pembuatan suatu peraturan perundang-undangan termasuk peraturan daerah wajib melalui tahapan pengkajian dan penyelarasan yang dituangkan dalam Naskah Akademik. Sebagaimana dalam Pasal 33 Ayat (3) UU No. 12 Tahun 2011, naskah akademik adalah naskah hasil penelitian atau pengkajian hukum dan hasil penelitian lainnya terhadap suatu masalah tertentu yang dapat dipertanggungjawabkan secara ilmiah. Lampiran I UU tersebut diatur sistematika naskah akademik yaitu terdiri dari 6 (enam) bab. Pada Bab IV memuat landasan Filosofis, Sosiologis, dan Yuridis.

Penelitian ini berfokus untuk mengkaji landasan sosiologis penyusunan Perda. Landasan sosiologis merupakan pertimbangan, pengkajian secara realitas di masyarakat yang meliputi kebutuhan hukum masyarakat salah satunya nilai-nilai yang hidup dan berkembang sehingga peraturan perundang-undangan yang hendak dibuat memiliki akar sosial yang kuat dalam hal nilai budaya Siri' Na Pacce suku Bugis-Makassar di Sulawesi Selatan. Hal ini dimaksudkan agar peraturan dapat berlaku secara efektif,

\footnotetext{
${ }^{13}$ Muhammad, Abdulkadir. (2004). Loc. Cit.
} 
sebagaimana didukung juga pandangan dari Eugen Elrich bahwa "hukum yang baik adalah hukum yang hidup dalam masyarakat"14

Berdasarkan hasil wawancara pada Aminuddin Salle berpendapat, bahwa terdapat 4 (empat) nilai dimensi Siri' yang dijunjung tinggi oleh masyarakat Bugis-Makassar, yakni: jujur, cerdas, kaya, dan berani.

Adapun penjelasan setiap dimensi nilai Siri' Na Pacce yang mengandung nilai anti korupsi sebagai berikut: Pertama, jujur dalam hal ini baik pada perbuatan maupun perkataan, sehingga bagi orang Bugis-Makassar yang hidup dengan nilai Siri' na pacce tidak akan mengambil yang bukan haknya atau dalam dunia sekarang tidak melakukan perbuatan korupsi; Kedua, cerdas dalam hal ini seseorang menanamkan nilai kecerdasan atau memiliki nilai kemanusiaan sehingga tidak akan mengambil hak orang lain atau tidak korupsi; Ketiga, kaya dalam konsepsi Siri' artinya merasa cukup sehingga tidak ada keinginan untuk mengambil hak orang lain. Keempat, berani dalam hal ini jika dia menganggap apa yang harus dikerjakan itu tidak benar termasuk tidak benar karena bukan hak-nya atau berani karena suatu kebenaran.

Juga ditambahkan penjelasan masyarakat Bugis-Makassar yang dahulu malu melakukan korupsi selain karena 4 (empat) dimensi nilai yang terkandung di atas, juga karena dalam dimensi nilai Siri' na pacce juga terdapat nilai berupa sanksi sosial dan moral yang tentu juga menjadi alasan sehingga orang tidak melakukan perbuatan mengambil hak orang lain. Hal ini semakin diperkuat pada fakta kajian pada suatu desa di Sulawesi Selatan membuktikan nilai Siri' na pacce membuat pengelolaan dana desa menjadi transparan dan akuntabel. Karena malu jika mengelola uang desa yang bukan hak-nya secara tertutup.

Tapi bagi Aminuddin sekarang 4 dimensi nilai yang terkandung dalam Siri' Na Pacce menghilang di masyarakat Bugis-Makassar sehingga perilaku korup semakin meningkat.

Menurut Aminuddin Salle, nilai budaya memang tidak tertuang dalam bentuk tulisan, namun dapat dikodifikasikan menjadi suatu norma apabila bermanfaat dan dapat diterima oleh masyarakat. Bahkan ditegaskan bahwa upaya ini belum terlambat, dan dapat dimulai dari bawah. Seperti pepatah Makassar yang mengatakan bahwa "Batturiawako Appaenteng" yang artinya "dari bawalah membangun". Kalimat ini membuktikan bahwa nilai-nilai Siri' harus ditanamkan pada anak-anak kecil, sebab apabila dari yang kecil saja sudah teguh maka seterusnya hingga tua akan teguh dalam hal kejujuran dan kebenaran.

Tidak jauh berbeda dengan pendapat narasumber yang pertama, Serang Dakko berdasarkan hasil wawancara juga berpendapat bahwa dalam Siri' Na Pacce mengandung nilai-nilai kejujuran, penjelasan ini diberikan dengan gambaran bahwa pada masa lalu (kerajaan) kesadaran akan Budaya

${ }^{14}$ Wahid, Muhammad Yunus. (2011). Loc. Cit. 
Siri' masih sangat kental karena dahulu dikenal suatu sanksi sosial yaitu "Kalau tidak Siri' (malu), pergi/keluar". Sehingga praktik korupsi masih sangat terkendali.

Kemudian, berkaitan dengan hal tersebut, Abdi Mahesa sebagai salah satu narasumber juga memperkuat pernyataan tersebut bahwa pada masa lalu, orang yang tidak jujur diusir dari lingkungannya atau bahkan dibunuh atau bunuh diri, karena masyarakat dahulu mempercayai bahwa jika kesalahan tidak diadili maka alam akan murka (Accilakang).

Abdi menambahkan masyarakat Bugis-Makassar memegang teguh pepatah yang mengatakan bahwa "Ulebbireng mate patetongi Siri' ku Nakkia tuo ri linoe tessiri NaNawaNawa" yang artinya "lebih baik mati tegakkan harga diri (rasa malu), daripada hidup di dunia resah dan memalukan".

Selain dari data primer diatas, yakni data dari ketiga narasumber, dalam penelitian ini juga menunjang data sekunder untuk mendapatkan hasil yang relevan yakni salah satunya jurnal Indigenous Vol. 13 No. 2, dengan judul Nilai Budaya Siri' Na Pacce dan Perilaku Korupsi. Yang dapat dilihat pada diagram berikut ini:

Mughny Ilman Rusdi dan Susanti Prasetyaningrum. Jurnal Indigenous Vol.

13 No. 2, dengan judul Nilai Budaya Siri' Na Pacce dan Perilaku Korupsi

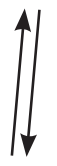

Pendapat Prof. Dr. H
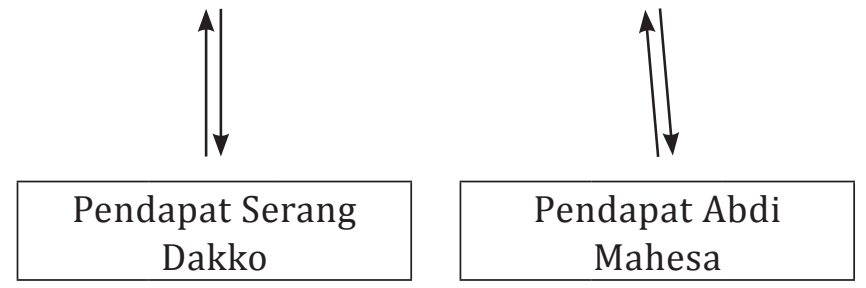

Dari hasil penelitian pada jurnal Indigenous menunjukkan bahwa Nilai Budaya Siri' Na Pacce memiliki korelasi yang negatif atau timbal balik dengan perilaku korupsi, sehingga nilai budaya Siri' Na Pacce dapat menjadi salah satu faktor untuk menekan perilaku korupsi, dan dengan menambah nilai-nilai budaya Siri' Na Pacce, perilaku korupsi dapat dicegah. Kemudian ketiga narasumber juga mengatakan bahwa adanya nilai anti korupsi dalam nilai budaya Siri' Na Pacce, yakni jujur, cerdas, kaya, dan berani. Keempat dimensi tersebut harus ditanamkan sejak dini, sebab jika seseorang mengimplementasikan nilai yang terdapat dalam budaya Siri' $\mathrm{Na}$ Pacce tersebut, maka tidak akan terjadi praktik korupsi. Dengan demikian, dapat disimpulkan dari diagram tersebut, ketiga pendapat narasumber (data primer) yang ditunjang dengan jurnal Indigenous (data sekunder) terbukti memang benar bahwa ada nilai anti korupsi dalam nilai budaya Siri' $\mathrm{Na}$ Pacce masyarakat Bugis-makassar.

Nilai budaya Siri' inilah yang dapat dijadikan kebijakan preventif (pencegahan) dengan menuangkan dalam bentuk Peraturan Daerah Kurikulum Mata Pelajaran Lokal Nilai-nilai Budaya Siri' Na Pacce di Sulawesi Selatan. Selain itu sebagai upaya represif yaitu dengan membuat perda secara khusus yang memuat sanksi bagi tindak pidana korupsi berupa sanksi 
pengusiran (sanksi tambahan) bagi setiap orang dan keluarganya yang melakukan tindak pidana korupsi, karena bagi orang suku Bugis-Makassar sanksi ini lebih ditakuti karena rasa malu sangat dijunjung tinggi ${ }^{15}$ sehingga sanksi seperti ini akan lebih efektif menekan angka korupsi di Sulawesi Selatan.

\section{SIMPULAN DAN SARAN}

Berdasarkan uraian diatas dapat disimpulkan bahwa dalam budaya Siri' Na Pacce sebagai pedoman hidup masyarakat Bugis-Makassar mengandung 5 (lima) dimensi nilai yang memiliki hubungan erat dengan nilai-nilai anti korupsi yakni: Jujur (Lempu'), Cerdas, Kaya, Berani, dan Accilakang. Sehingga dapat dijadikan upaya preventif dan represif untuk mencegah dan memberantas tindak pidana korupsi di Sulawesi Selatan.

Untuk mencegah dan menekan praktik korupsi di Sulawesi Selatan, maka pemerintah perlu memasukkan nilai-nilai budaya Siri' Na Pacce dalam kehidupan masyarakat Bugis-Makassar dengan cara membuat Peraturan Daerah Anti Korupsi yang memuat sanksi tambahan berupa Accilakang yaitu sanksi diusir dari komunitas atau sanksi sosial lainnya dan Peraturan Daerah Kurikulum Pembelajaran Nilai-Nilai Anti Korupsi Pada Siswa di Sulawesi Selatan.

\section{UNGKAPAN TERIMAKASIH}

Ucapan terima kasih kepada Kementerian Riset, Teknologi, dan Pendidikan Tinggi Republik Indonesia yang telah memberikan kepercayaan dan membantu pendanaan kepada mahasiswa Fakultas Hukum Universitas Muslim Indonesia dalam Program Kreatifitas Mahasiswa.

\section{DAFTAR RUJUKAN}

Azis, Nur Alimin, Mangoting, Yenni, \& Lutfillah, Novrida Qudsi. (2015). Memaknai Independensi Auditor dengan Keindahan Nilai-Nilai Kearifan Lokal Siri' Na Pacce. Jurnal Akuntansi Multiparadigma, Universitas Brawijaya bekerjasama dengan Masyarakat Akuntansi Multiparadigma Indonesia, 6(1), 145 - 156.

Barlian, Aristo Evandy A. (2016). Konsistensi Pembentukan Peraturan Daerah Berdasarkan Hierarki Perundang-Undangan dalam Perspektif Politik Hukum. Fiat Justisia: Jurnal Ilmu Hukum, Universitas Lampung, 10(4), $605-622$.

D., Mukti Fajar N., \& Achmad, Yulianto. (2015). Dualisme Penelitian Hukum: Normatif \& Empiris. Yogyakarta: Pustaka Pelajar.

${ }^{15}$ Qamar, Nurul, Badaru, Baharuddin, \& Aswari, Aan. (2017). Local Wisdom Culture of Bugis-Makassar in Legal Perspective. Paper presented at the 12th ADRI 2017 International Multidisciplinary Conference, Bogor, hlm. 87. 
Pleno Jure, Vol. 9 (2), Fadillah Gerhana Ultsani, Menggali Nilai Siri' Na Pacce ...

Darwis, Rizal, \& Dilo, Asna Usman. (2012). Implikasi Falsafah Siri' Na Pacce pada Masyarakat Suku Makassar di Kabupaten Gowa. El-Harakah: Jurnal Budaya Islam, Universitas Islam Negeri Maulana Malik Ibrahim, 14(2), $186-225$.

Fazzan. (2015). Korupsi di Indonesia dalam Perspektif Hukum Pidana Islam. Jurnal Ilmiah Islam Futura, Institut Agama Islam Negeri Ar-Raniry, 14(2), $146-165$.

Istanto, F. Sugeng. (2007). Penelitian Hukum. Yogyakarta: CV. Ganda.

Marzuki, M. Laica. (1995). Siri': Bagian Kesadaran Hukum Rakyat BugisMakassar. Ujung Pandang: Hasanuddin University Press.

Muhammad, Abdulkadir. (2004). Hukum dan Penelitian Hukum. Bandung: PT. Citra Aditya Bakti.

Qamar, Nurul, Badaru, Baharuddin, \& Aswari, Aan. (2017). Local Wisdom Culture of Bugis-Makassar in Legal Perspective. Paper presented at the 12th ADRI 2017 International Multidisciplinary Conference, Bogor.

Qamar, Nurul, Syarif, Muhammad, Busthami, Dachran S., Khalid, Hasbuddin, Rezah, Farah Syah, \& Muzakkir, Abd. Kahar. (2018). Menguak Nilai Kearifan Lokal Bugis Makassar: Perspektif Hukum dan Pemerintahan. Makassar: CV. Social Politic Genius (SIGn).

Rusdi, Mughny Ilman Wali, \& Prasetyaningrum, Susanti. (2015). Nilai Budaya Siri' Na Pacce dan Perilaku Korupsi. Indigenous: Jurnal Ilmiah Psikologi, Universitas Muhammadiyah Surakarta, 13(2), 68 - 86.

Sina, La. (2008). Dampak dan Upaya Pemberantasan Serta Pengawasan Korupsi di Indonesia. Pro Justitia, Universitas Katolik Parahyangan, 26(1), $39-51$.

Srinita, Ibu. (2016). Strategi Menihilkan Korupsi di Sektor Pendidikan dan Kesehatan. Poelitik: Jurnal Kajian Politik, Ekonomi Politik dan Masalah Pembangunan, Universitas Nasional, 12(2), 1891 - 1902.

Swamy, Anand, Knack, Stephen, Lee, Young, \& Azfar, Omar. (2001). Gender and Corruption. Journal of Development Economics, 64(1), 25 - 55.

Syamsuddin, M. (2007). Operasionalisasi Penelitian Hukum. Jakarta: PT. Raja Grafindo Persada.

Syihabudin. (2003). Kajian terhadap Jenis dan Tata Urutan Peraturan Perundang-Undangan Indonesia. Jurnal Hukum Ius Quia Iustum, Universitas Islam Indonesia Yogyakarta, 10(23), 46 - 71.

Undang-Undang Dasar Negara Republik Indonesia Tahun 1945.

Undang-Undang Republik Indonesia Nomor 31 Tahun 1999 Tentang Tindak Pidana Korupsi. 
Pleno Jure, Vol. 9 (2), Fadillah Gerhana Ultsani, Menggali Nilai Siri' Na Pacce ...

Undang-Undang Republik Indonesia Nomor 30 Tahun 2002 Tentang Komisi Pemberantasan Tindak Pidana Korupsi.

Undang-Undang Republik Indonesia Nomor 12 Tahun 2011 Tentang Tata Urutan Perundang- Undangan.

Undang-Undang Republik Indonesia Nomor 9 Tahun 2015 Tentang Perubahan Kedua Atas Undang-Undang Nomor 23 Tahun 2014 Tentang Pemerintahan Daerah.

Wahid, Muhammad Yunus. (2011). Prinsip dan Karakter Hukum Lingkungan. Ishlah: Jurnal Ilmiah Hukum, UMI Makassar, 13(2). 